\title{
The Health Services Legal Problems of In Vitro Fertilization (IVF) Program Patients in Indonesia
}

\author{
Edi As'Adi ${ }^{1}$, Norma Sari ${ }^{2}$ \\ ${ }^{1}$ Faculty of Law, Universitas Ahmad Dahlan, Indonesia \\ edi.asadi@law.uad.ac.id \\ ${ }^{2}$ Faculty of Law, Universitas Ahmad Dahlan, Indonesia, \\ norma.sari@law.uad.ac.id
}

\begin{abstract}
Introduction to The Problem: Every married couple expects children that the Constitution guarantees. However, the difficulty of having a child tends to be a problem in maintaining married life. Some couples decide to have a child by undergoing In Vitro Fertilization (IVF) Program. The arising problems are on how the current regulation of the IVF program and how to fulfil the rights of IVF program patients from consumer protection law.
\end{abstract}

Purpose/Objective Study: This article focus on the problem of health services for IVF program patients based on the values of justice on the ground of consumer protection law in Indonesia.

Design/Methodology/Approach: This study is socio-legal research. However, to support the validity of research, an empirical approach is critical to do-furthermore, where data obtained through interviews based on the researcher's own experience.

Findings: IVF program agreement between the IVF clinic and patients is a law based on Article 1338 of the Indonesian Civil Code. Even so, the research validation was still carried out with the support of an empirical approach. The results of this research are that the current IVF program has not been able to protect its patients' rights. Patients' position tends to be weak compared to the clinic or IVF hospital; the concept of the IVF program implementation agreement does not protect patient rights. In the future, attempts to protect IVF patients' rights need an integrated and comprehensive regulation from the philosophical, juridical, and sociological basis to its practical implementation.

Paper Type: Research Article

Keywords: Protection; Patients; In Vitro Fertilization; Consumers

\section{Introduction}

Every Indonesian citizen's constitutional right to have offspring is a human right that the State must guarantee. Normatively, this guarantee has been formulated in Article 28B Paragraph 1 of the 1945 Constitution of the Republic of Indonesia. Namely, that "everyone has the right to form a family and continue offspring through a legal marriage." 


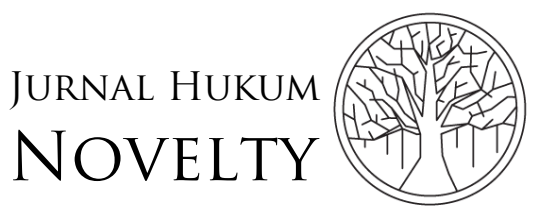

Volume 12, Issue 01, 2021, pp. 109-123

P-ISSN: 1412-6834

E-ISSN: 2550-0090

Starting from the mandate of the Constitution, the emergence of a debate related to the focus of the study of problems in health services for IVF patients based on the value of justice in Indonesia, in general, has become part of the main discussion by the Indonesian People's Consultative Assembly in the field of Human Rights. Thus, it is outlined in the People's Consultative Assembly (MPR) Decree No. XVII/TAP/MPR/1998, which has a full sound as follows: Article 1 stated that everyone has the right to live, defend life and life; Article 2 stated that everyone has the right to form a family and continue their offspring through a legal marriage; and Article 3 stated that everyone has the right to fulfil his basic needs to grow and develop properly (Elvina, 2014).

However, in the field of fact (das sain), it is very different from the legal provisions of das Sollen above. Legal data show that the divorce rate due to having no children in the household shows an increasing trend every year. Among them are Decision No. 164/Pdt.G/2012/PA.Clg. In this decision, the husband (the Petitioner) gave divorce to his wife (the Respondent) because they did not have children since they were married on July 29, 2005. Despite the fact, the judge's purport's legal product was considered based on Article 39 Paragraph (2) letter f of the Law Number 1 of 1974 concerning Marriage jo Article 19 letter f Government Regulation Number 9 of 1975 jo Article 116 letter $\mathrm{f}$ Islamic Law Compilation. This trend shows that there has been a shift in the dynamic pattern of community law, which should (das Sollen) be an instrument for shaping order in society. Still, at a practical level, it tends to cause chaos in society. Observing legal phenomena like this can be said that the law that should provide happiness, legal certainty, and justice for all Indonesian people is constantly changing, along with society's development (Raharjo, 2008). Furthermore, from the medical perspective, the problematic implementation of the normative provisions above is considered a breakthrough to actualize the Constitution's ideals by providing health services for pregnancy programs through IVF through reproductive technology with in vitro fertilization (IVF) methods and embryo transfer. The basis is in Article 1 point (1) Instruction of the Minister of Health of the Republic of Indonesia Number 379/MENKES/INST/VIII/1990 regarding IVF Service Program.

This effort is good news for a married couple who have not had children for a relatively long time. However, another problem arises when the IVF program that patients follow does not provide optimal results as expected. Starting from such a background of thought, the researcher is interested in examining the inner library with a comprehensive and interdisciplinary scientific review. With limitations, the study focuses on the following sub-studies: What are the current regulations for implementing the IVF program? Moreover, how to fulfil the rights of IVF program patients from the perspective of consumer protection law? 


\section{Methodology}

This research uses the socio-legal method. However, to support the validity of research, an empirical approach is critical to do-furthermore where data obtained through interviews based on the researcher's own experience. According to Edwin W. Patterson (1963) and Oliver Wendell Holmes (2002), as quoted by Peter Mahmud Marzuki (Marzuki, 2004) states that using scientific methods in legal methods does not touch things that are perspective. However, it is an empirical approach or an approach based on experience (law in action) that: "the life of the law has not been logic; it has been experienced..." Thus, the law in action approach is intended to extract information directly from primary data sources in the field, which is further supported by secondary data (Soerjono, 1986).

\section{Results and Discussion}

\section{Implementation Regulations Related to Current IVF Program Patient Services}

Principles of Patient Health Services in IVF Program Perspective of Law No. 25 of 2009 concerning Public Services

Public health is one of the critical priorities, which is the State's goal to achieve general welfare. Likewise, guarantees for reproductive health services through medical technology tend to be increasingly needed by some people with health problems to have or continue offspring (Breslin \& Cambell, 1999).

The principle of health services is a part of public services that should be based on non-discrimination, transparency, and affordable costs to all people, as stipulated in Law No. 25 of 2009. These principles can be presented as follows:

1. Simplicity: Public service is an excellent service if its implementation is not problematic, procedures/service procedures are carried out efficiently, smoothly, quickly, without complicated procedures, easy to understand, and easy to implement by the community requesting service.

2. Clarity and Certainty Clarity: this public implementation includes clarity in terms of:

a. Technical and administrative requirements of the public services;

b. Public service procedures;

c. Work unit/official who is authorized and responsible for providing services and resolving complaints/problems/disputes in public services implementation;

d. Details of fees/rates for public services and payment methods;

e. Schedule of public service completion time;

f. Officials who receive public complaints if there is unclear and/or not satisfied with the community's services.

Furthermore, Law Number 25 of 2009 concerning Public Services states, several components of good public service standards, as well as services to IVF program patients, are as follows: 
1. The legal basis of every form of public service policy issued by government agencies as service providers must have a legal basis which is legalized by legislation to indicate that the services provided are public legal services according to laws and regulations.

2. Systems, Mechanisms, and Procedures, the form of public services provided by a government agency, must have a transparent system. This implementation mechanism is easily implemented by the whole community and must have procedures.

a. Duration of Completion, Public services provided by government agencies in their implementation must have a time limit for efficient completion of activities. Public services provided to the community are carried out in a short standard time.

b. Fees/tariffs, public services are essentially a form of service provided to the community. Therefore, the costs or rates given must have a standard price that the community can reach. In other words, the price of public services is low.

c. Service Products, services provided by an organization, are public services if the produced products are public goods, public service, and administration service.

d. Facilities and infrastructures, the effectiveness of public services provided by the organization are seeable from the availability of facilities and infrastructure in providing services. There are adequate facilities for the convenience of customers or the community.

e. Implementing Potential, Public service providers must have expertise, creativity, and abilities regarding attitudes and behaviour in providing services to customers or society.

f. Handling Complaints, Suggestions, and Inputs. Every government organization must have the means to accommodate the community's aspirations, which contain criticism, suggestions, and complaints. It aims at improving the quality of public service delivery to the community.

g. Number of Implementers, government organizations have adequate service providers so that the implementation of service delivery can run effectively.

Appropriate health services for IVF Program patients, based on the public services principles, will lead to the assurance and guarantee to the success of the IVF Program patients who expect to get offspring.

Health Services of IVF Program Patients Principles Based on Law No. 36 of 2009 concerning Health

The success of IVF program patients is a priority that the doctors and/or clinics and hospitals providing IVF program services should guarantee. It is the mandate of Law No. 23 of 2009 concerning Health. The author can fully explain the mandate as follows: 
1. The principle of legality of Article 23 of Law No. 36 of 2009; These provisions must meet the permits: equalize and improve service methods quality. Certainty, protection for implementing professional autonomy to anticipate act against the law in carrying out private palmed practices, is solely commercially oriented.

2. Principle of Balance Elucidation of Article 2 paragraph (2) of Law No.36 of 2009 Law that restores the balance of the disturbed community order to its original state Health administration must balance physical and mental between material and spiritual. Balance: a) between goals and means, b) between means and results c) between benefits and risks.

3. This principle of balance provides a position for the interests of patients and doctors. This principle is closely related to justice, as stated in the explanation of Article 2 paragraph (6) of Law No. 36 of 2009 (the principle of justice means that health administration must provide fair and equitable services to all levels of society with affordable financing).

a. Punctuality Principle; This principle is essential because negligence in providing proper assistance at the time needed can cause harm to patients (Article 29 of Law No. 39/2009). Everyone has the right to compensation due to health workers' errors or negligence (Article 58 (1) Law No. 36/2009). Based on the principle of being on time: an action that must be taken immediately in the context of medical services for the patient's benefit cannot be postponed an eye solely for the personal benefit of the doctor.

b. The principle of punctuality is closely related to the principle of good faith (goede trouw). This principle provides consideration for whether or not Informed Consent (IC) is needed in therapeutic transactions.

c. The principle of good faith agreement must be carried out in good faith (Article 1338 paragraph (3) of the Civil Code) and based on ethical norms (bonafides) by doing good. This principle is applied in implementing a doctor's obligation to meet professional standards (Article 27 paragraph (2) of Law No. 36/2009).

d. The Principle of Doing Good (Article 1354 of the Civil Code). In medical services: based on patient trust, the doctor in good faith shall provide quality and dignified professional help with sincerity following his/her responsibility. A person is obliged to help others as long as a) Does not pose a risk to himself or herself; b) The person being helped has tried to help himself.

e. Principles of Honesty is one of the factors that can lead to an attitude of trust. In medical services: doctors shall assist according to what patients need and according to professional standards. The use of available facilities and infrastructure is only carried out according to the patient's needs. Delivery of information, patient-oriented interests Honesty is the truth of information. Not all truth must be conveyed to the patient if it is detrimental to the patient-attitude and quality of communication in medical interviews. The principle of honesty underlies the doctors' obligation to meet professional 
standards and respect patient rights (Articles 7, 8 and Article 56 of Law No. 36 of 2009).

f. Precautionary principle; In medical services, doctors must have expertise and skills and accuracy in acting according to professional standards. Ethical principles are not harmful, nor do they harm others. Even though they pose a risk of loss, the patient is entitled to compensation.

Starting from the description above, the writer can draw a common thread on the relationship between IVF patients' success with the responsibility of the doctor's profession as an organ of health services as an obligation. As a professional in the medical field, in providing health services to the IVF program, doctors shall not harm others (Primum Non-Nocere). It means that every medical action carried out by a doctor as a professional should be held responsible for errors or negligence in carrying out.

\section{Health Services of IVF Program Patients Principles Based on Law No. 29 of 2004 concerning Medical Practice}

The basis of the value of justice in health services for IVF patients is essential that every doctor must prioritize in carrying out his profession. It means that specialist doctors profession in IVF reproduction is responsible and guarantees success and patient satisfaction to get the desirable offspring. It is emphasized in Article 2 of Law No. 29 of 2004, which states that "medical practice is implemented based on Pancasila and based on scientific values, benefits, justice, humanity, balance, and patient protection and safety."

From these normative provisions, a conclusion can be drawn that there is a need for legal sanctions and guarantees for IVF program patients to guarantee their rights by doctors who are administering the IVF program. Namely, through an explicit agreement as regulated in Article 1320 of the Civil Code, the agreement is a law that must be respected and carried out by the parties who make it, according to Article 1338 of the Civil Code.

Health Services of IVF Program Patients Principles Based on the Ministry of Health Regulation Number 43 of 2015 concerning the Implementation of Reproductive Services with Assistance or Pregnancy Outside the Natural Way Special services in handling IVF program patients are a form of constitutional mandate. Therefore, the government emphasizes the standard of service for IVF patients to get offspring in Indonesian Ministry of Health Regulation Number 43 of 2015 concerning Implementation of Reproductive Services with Assistance or Pregnancy Outside the Natural Way (hereinafter as referred to as MoH Regulation No. 43 of 2015). The rights to get offspring through IVF service have been formulated in Article 1 point (1). The article states that "Assisted Reproductive Services or Pregnancy Outside the Natural Way, hereinafter referred to as Assisted Reproductive Technology Service, is an effort to obtain a pregnancy outside the 
natural way without undergoing the process of conjugal relations (intercourse) if natural methods do not get results, by bringing together the husband's spermatozoa with the wife's egg in the tube."

Furthermore, health services for IVF program patients can only be administered with a government permit as stated in Article 1 point (2) of the said Ministry of Health Regulation, that "Assisted Reproductive Technology Service Operation Permit, hereinafter referred to as Permit, is a permit given to the operator health service facilities to provide Assisted Reproductive Technology Services". Then, Article 2 states that "Assisted Reproductive Technology Services are only carried out in general hospitals and special hospitals for mothers and children."

The requirements that must be fulfilled by health service providers for IVF program patients are formulated in Chapter II Article 3 of the above Minister Regulation, namely that hospitals that provide Assisted Reproductive Technology Services must meet the requirements which include:

1. energy;

2. administration and management; and

3. facilities, infrastructure, and equipment.

Furthermore, to provide services to IVF patients, other requirements that administrators of the IVF program must fulfil as regulated in Article 4 paragraph (1), namely the availability of Assisted Reproductive Technology Service personnel Requirements as referred to in Article 3 letter a consists of:

1. medical staff;

2. implementing health personnel; and

3. other executive personnel.

Article 4 paragraph (2) states that medical staff, as referred to in paragraph (1) letter a, have at least the following educational background: a) obstetrician and gynaecologist with the subspecialty of reproductive endocrinology and fertility; b) specialist obstetricians and gynaecologists with additional competence assisted reproductive technology services and gynaecological endoscopy (laparoscopy, hysteroscopy); c) urologist specialist with additional competency Assisted Reproductive Technology Services, reproductive endocrinology in men; d) andrology specialist with additional competence in assisted reproductive technology, reproductive endocrinology in men, and e) a doctor with additional competence in tissue culture, oocyte maturation, fertilization, and zygote division.

Furthermore, according to Article 4, paragraph (3) confirms that the implementing health personnel, as referred to in paragraph (1) letter $b$, have at least an educational background: a) Diploma Three of Nursing, additional competencies of Assisted Reproductive Technology Services; and b) Diploma Three health analysts for the scope of work assisting in tissue culture and andrology laboratory services. Article 4 paragraph (4), it is also stated that the other implementing staff, as 


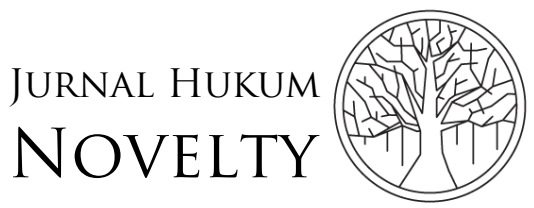

Volume 12, Issue 01, 2021, pp. 109-123

P-ISSN: 1412-6834

E-ISSN: 2550-0090

referred to in paragraph (1) letter c, have at least an educational background: a) veterinarian; or b) biology graduate with additional competencies in tissue culture, oocyte maturation, fertilization, and zygote division. According to Article 8 (1), the equipment, referred to in Article 3 letter c, must have a distribution license and be calibrated periodically following the provisions of laws and regulations. (2) As intended in paragraph (1), the equipment is listed in the Attachment, an integral part of this Ministerial Regulation.

To protect the rights and responsibilities of providing health services for the IVF program, patients must also have a license as regulated in Article 9 paragraph (1) of this MoH Regulation No. 43 of 2015, namely that every Assisted Reproductive Technology Service Provider must have a license. Paragraph (2) regulate that the license is an Operating License issued by the Director-General on behalf of the Minister. Paragraph (3) regulate that the license, as referred to in paragraph (2), is valid for 5 (five) years and can be extended as long as it meets the requirements. Next, paragraph (4) states that the license extension as referred to in paragraph (3) shall be carried out by applying for an extension not later than 6 (six) months before the Operating Permit expiration. Article 10 (1) states that to obtain a permit, the head of health service facilities must apply to the Director-General. Then, Article 10 (2) states that the application as intended in paragraph (1) shall be accompanied by complete requirements: a) hospital operational permit; b) provincial health office recommendation; c) The profiles of Assisted Reproductive Technology Service Providers containing data on personnel, infrastructure, equipment, and procedures/methods used; and, d) Self-assessment forms that have been filled in. Next in Article 10 (3) states that self-assessment forms, as referred to in paragraph (2) letter d, are filled in as contained in Form 2, which is an integral part of this Ministerial Regulation.

According to Benjamin (Benjamin, 2000), the arrangements related to the process of providing services to IVF program patients as regulated in Article 13 (1), Assisted Reproductive Technology Services are carried out by: a) conventional, and b) Intra Cytoplasmic Sperm Injection (ICSI). Article 13 (2) states that Conventional Assisted Reproductive Technology Services, as referred to in paragraph (1) letter a, shall be carried out by bringing together the normal husband's spermatozoa and the wife's oocyte in a tube. Then, the formed embryo is transferred into the wife's womb. Article 13 (3) regulate that Assisted Reproductive Technology Services using Intra Cytoplasmic Sperm Injection (ICSI) referred to in paragraph (1) letter b is carried out by direct injection of husband's spermatozoa into the wife's oocyte. Next, Article 13 (4) states that Assisted Reproductive Technology Services through Intra Cytoplasmic Sperm Injection (ICSI), as referred to in paragraph (3), shall be implemented if the quality of spermatozoa is very poor embryo formation.

Based on the description of the normative provisions above, a common thread can be drawn between the IVF program patient service agreement and the level of 
guarantee for the patient's success to get offspring. Both are the benchmarks for administrators' success in providing IVF program services for the community, as confirmed in Article 16 above.

\section{Rights of IVF Program Patients from Consumer Protection Law Perspective}

The guarantee and protection of IVF program patients' rights can be carried out by normative juridical provisions in the form of legal products based on the value of justice and agreements between patients and doctors, and clinics hospitals that provide IVF program. Thus, the effort to realize orderliness in the care of IVF program patients can be realized according to patients' expectations to have offspring. Through laws and agreements that reflect philosophical, juridical, sociological, and historical aspects, the nation and State's life must be sustainable (As'adi, 2014).

According to Blair (Blair, 2000), the need for IVF programs is tending to increase. It is in line with the number of IVF patients, which tends to continue to grow. According to data from the Central Statistics Agency (Badan Pusat Statistik, 2008), the number of couples who experience fertility problems reaches 10 per cent of all couples in Indonesia or up to 4 million people. As many as five per cent, or 200,000 couples, must be assisted by IVF programs. However, until 2011, Indonesia only conducted five thousand IVF programs. That number lags far behind other countries in Southeast Asia.

According to the report of The World Bank (Shah, 2005), there are eight levels of indication of the effectiveness of health services as follows:

1. Physical accessibility: One approach to measuring accessibility is to measure the service supply relative to the population served; for example, the number of clinics per 1,000 population. However, this approach does not account for the distribution of services with respect to the poor. The data will be meaningful if they are broken down by district to compare the rural versus the urban or poor versus non-poor or consider the physical size of the area served and the population in the area. Suggestions for data collection and analysis include linking health maps with poverty maps and household surveys.

2. Availability of human resources: Shortages of qualified staff limits access, especially to the poor. Data collection suggestions include collecting data on health personnel in the public, private, and NGO sectors.

3. Availability of material resources: Shortages of drugs or equipment are almost the provision of health services. Suggestions for data collection and analysis include collecting data on the availability and distribution of equipment, drugs, and other inputs from central health information systems or conducting surveys of a sample of facilities (for example, essential drugs surveys).

4. Organizational quality and consumer responsiveness: Several factors influence the user-friendliness of services, including the attitude of health staff, hours of operation, waiting time, the gender of the service provider, and modes of 
payment. Suggestions for data collection and analysis in this area include qualitative surveys, focus groups, exit interviews with patients, on-site assessment, and situation analysis. Situation analysis (which was developed for family planning but may be adapted for other services) combines various methodologies to collect information from a sample of facilities and communities on the availability of inputs, provider behaviour, process quality indications, and community perceptions.

5. Social accountability: Health staff members in government clinics are often unresponsive to the poor because they are not directly accountable. Data on the ability of the poor to exert influence on services may be collected through visits to a sample of communities and facilities, possibly by an NGO in collaboration with communities.

6. Relevance and utilization of services: Utilization, a consumer's first use of services in a given year, is a key indicator of the extent to which the poor come in contact with the health system. Data on utilization can be gathered from health information system (numbers of visits, patient, vaccinations), household surveys (for information on the percentage of a target population using a particular service), and by linking (with a poverty map) the number of services produced in a specific area to income levels by area.

7. Continuity and timing of interventions: Timing and continuity examine whether consumers receive the requisite number of contacts for services that require repeated interventions and whether time-sensitive services (such as prenatal, maternal, and emergency) are delivered promptly. These can be assessed by looking at dropout rates and other follow-up indicators, preferably using a combination of facility data and household surveys.

8. Technical quality: The sector's capacity to provide the appropriate combination of technology and empathy at a given level of utilization is key to ensure that interventions are translated into effective outcomes. However, quality can be difficult to measure. Suggestions for data collection and analysis include compiling information on perinatal mortality rates, malaria fatality rates, tuberculosis cure rates, and maternal mortality. In addition, the WHO's Topical List of Priority. Indicators for IMCI at the Health-Facility Level provide a useful instrument for assessing quality in childhood illness management.

Based on the description of the eight health service identifications above, it shows that health services for IVF program patients have a high priority scale and should be accounted for by the clinic or hospital providing the IVF program.

Law No. 36 of 2009, as an amendment to Law No. 23 of 1992 on Health in Article 16 paragraph 1, regulate that "pregnancy outside the natural way can be implemented as a last resort to help husband and wife get offspring." Furthermore, in Paragraph 2 , it is emphasized that "efforts to conceive outside the natural way as referred to in paragraph one can only be carried out by a legally married couple with several provisions." Furthermore, Article 127 of Law No. 36 of 2009 states that a legally 
married couple with provisions can only carry out attempts at pregnancy outside of the natural way:

1. Fertilization result of the sperm and ovum of the husband and wife concerned is implanted in the wife's womb from which the ovum originates;

2. Carried out by health workers who have the expertise and authority to do so; and,

3. Carried out in certain health service facilities.

Judging from the practical level that the normative provisions regarding IVF refer to Government Regulation No. 61 of 2014 concerning Reproductive Health. Article 40, paragraph 1, states that assisted reproduction or pregnancy other than natural means can only be carried out on married couples bound by a legal marriage and experiencing infertility or infertility to obtain offspring. Furthermore, in paragraph 2 , it is emphasized that reproduction with assistance or pregnancy outside the natural way, as referred to in paragraph 1 , is carried out by using the results of fertilization of sperm and ova from the husband and wife concerned and implanted in the womb of the wife where the ovum originates.

Based on the legal provisions above, it is explicitly emphasized that to realize the ideal goal of Article 28B of the 1945 Republic of Indonesia Constitution above, it shows that the State has the responsibility to help its people who tend to find difficulties in having children in their household. Therefore, breakthroughs have been made in the field of Obgyn specialist medicine. A record must be following applicable legal norms and not violate decency.

Article 1 number 2 Law of the Republic of Indonesia Number 25 of 2009, namely that public service providers, hereinafter referred to as Providers, are any State administering institution, corporation, independent institution established by law for public service activities, and other legal entities formed solely for public service activities. Bird (2010) explains that good public service is a good implementation of tax revenue. The relevance of the hospital providing the IVF program as a public service institution with the level of patient satisfaction should be a benchmark that should always be considered. According to some consumer protection adherents, this is the right of consumers to get satisfaction and protection from business actors.

\section{Fulfilling the Rights of IVF Program Patients from Consumer Protection Perspective}

Robert M. Unger believes that jurists had attempted to create legal structures based on the ideas of democracy and free markets in the nineteenth century. The free market is expected to benefit capitalism if the balance between supply and demand is guaranteed by democracy (Samekto, 2014). The dynamics of society show that basically, the existence of law results from changes in society (As'adi, 2014; Sulistyanta, 2013). Thus, the view of Robert M. Unger above shows that the balance between rights and obligations in a civil law relationship is freedom in the free 
market if guaranteed by democracy. Likewise, there are limits on their rights and obligations in the legal relationship between patients and hospitals that provide IVF program services.

This relationship is regulated in Republic of Indonesia Law Number 29 of 2004 concerning Medical Practice in legal substance. All activities related to the hospital's duties for IVF programs must be following the principles and objectives carried out based on Pancasila and based on scientific values, benefits, justice, humanity, balance, and patient protection and safety.

Based on the description above, medical science is relevant in the field of IVF program services and law on the principle of freedom of contract (pacta sun servanda) between IVF clinics and their patients, according to Article 1338 paragraph (3) of the Civil Code. Thus, in a legal relationship, the two parties require good faith following Article 1320 of the Civil Code. In line with this thought, it can be concluded that in principle, everyone's rights and obligations are the same and are guaranteed by law, likewise, in terms of rights and obligations of IVF Program Patients. Constitutionally, it is also stated in the Basic Law Article 28 B paragraph (1) regarding every person has the right to form a family and continue their offspring through a legal marriage.

Apart from the Constitution mentioned above, there are still normative provisions that can be the basis for limiting IVF patients' rights and obligations, namely Article 1320 Civil Code, Article 1338 of the Civil Code, and Article 1365 of the Civil Code. However, in a lex specialist the provisions governing limits regarding the rights of patients as regulated in the Law of the Republic of Indonesia Number 29 of 2004 concerning Medical Practice, the rights of patients are as follows (Tinungki, 2019):

1. The patient will receive a complete explanation of the medical action plan to be performed by the doctor;

2. The patient can ask another doctor's opinion;

3. Patients receive medical services according to their needs;

4. The patient can refuse the medical action that the doctor will take if there is any doubt;

5. Patients receive medical record information.

Based on the juridical review above, it can be observed that the patient's position is free in determining the type of health service, especially the IVF program. However, most of the patients are ordinary people who do not understand medical science in detail. So that not infrequently, patients tend to follow the doctor's instructions. The patient is also obliged to convey everything that the doctor has felt and found from laboratory examinations and other diagnoses. These obligations are as follows:

1. Patients are required to provide complete, honest, and understood information about their health problems;

2. The patient obeys the doctor's advice and instructions; 
3. Patients comply with the applicable provisions in health service facilities;

4. The patient provides compensation for services received.

In terms of consumer protection, patient rights and obligations can also be compiled in the Law of the Republic of Indonesia Number 8 of 1999 concerning Consumer Protection. Article 4 grants several rights of IVF program patients as consumers, namely:

1. the right to comfort, security, and safety in consuming goods and/or services;

2. the right to choose and obtain goods and/or services following the exchange rate and conditions and guarantees promised;

3. the right to correct, clear, and honest information regarding the condition and guarantee of goods and/or services;

4. the right to hear their opinions and complaints about the goods and/or services used;

5. the right to obtain advocacy, protection, and efforts to properly resolve consumer protection disputes;

6. the right to receive consumer guidance and education;

7. the right to be treated or served properly and honestly and not discriminatory;

8. the right to get compensation, indemnity, and/or replacement of the goods and/services received are not following the agreement or not as they should be;

9. rights regulated in the provisions of other laws and regulations.

The rights described above are broader in scope regarding the fundamental rights of consumers, which were first put forward during the congress by the President of the United States J.F. Kennedy, including:

1. the right to security;

2. the right to vote;

3. right to information;

4. the right to be heard.

Based on the four fundamental rights conveyed by J.F. Kennedy is part of the Declaration of Human Rights drafted by the United Nations, to be precise, on December 10, 1948. In Articles 3, 8, 19, 21, and Article 26, four basic consumer rights were added by the World Consumer Organization (International Organization of Consumers Union-IOCU, 1991), i.e.:

1. the right to obtain the necessities of life;

2. the right to obtain compensation;

3. the right to receive consumer education;

4. the right to a clean and healthy living environment.

Unlike the case with the European Community (Europese Ekonomische Gemeenschap or EEG) which has agreed on five basic consumer rights, namely:

1. the right to protect health and safety (recht op bescherming van zijn gezendheid en veiligheid); 
2. the right to protect economic interests (recht op becherming van zijn economische belangen);

3. the right to receive compensation (recht op schadevergoeding);

4. lighting rights (recht op voorlichting en vorming);

5. the right to be heard (recht om te worden gehord).

Various kinds regarding the formulation of consumer rights have been described. However, the formulation of consumer rights can be drawn outlines and can be used as basic principles, namely:

1. rights intended to prevent IVF patients from avoiding losses that may arise in the future;

2. patients get the right to obtain services from the hospital at a reasonable price as it should have been standardized in a predetermined policy;

3. the right to obtain an appropriate solution to the problems faced by IVF patients.

\section{Conclusion}

Based on normative juridical provisions, doctors, hospitals, and or clinics that provide IVF programs are obliged to provide excellent and measurable services to IVF program patients to get offspring through reproductive technology. That to guarantee the rights of patients, the law also regulates that there is at least a clear agreement that can provide legal certainty, fairness, and benefits to patients in carrying out IVF programs. Thus, the agreement for patient health services in the IVF program becomes a benchmark for the profession of doctors and hospitals or clinics that provide IVF as regulated in law.

\section{References}

As'adi, E. (2014). Problematika Penerapan Asas Recklessness Dalam Perspektif Pembaharuan Hukum Lalu Lintas Di Indonesia. Jurnal Dinamika Hukum, 14(3), 490-503. https://doi.org/10.20884/1.jdh.2014.14.3.313

Badan Pusat Statistik, (2008). Statistik Indonesia, Statistical Yearbook of Indonesia 2008. Publication Number: 07330.012, BPS Catalogue: 1101001. ISSN : 01262912, 1-653.

Benjamin, S. (2000). Governance, economic settings and poverty in Bangalore. Environment and Urbanization, 12(1), 35-56. https://doi.org/10.1177/095624780001200104

Bird, R. M. (2010). Threading the fiscal labyrinth: some issues in fiscal decentralization. Tax Policy in the Real World, 46(2), 141-162. https://doi.org/10.1017/cbo9780511625909.009

Blair, H. (2000). Participation and accountability at the periphery: Democratic local governance in six countries. World Development, 28(1), 21-39. https://doi.org/10.1016/S0305-750X(99)00109-6

Breslin, P., \& Cambell, D. (1999). Giving a community the Authority to Distribute Public Funds Creates a Dynamic of Efficiency and Accountability. Grassroots Development 22 (1), 28-30. 
Elvina, S. N. (2014). Perlindungan Hak untuk Melanjutkan Keturunan dalam Surrogate Mother, 1-24.

Marzuki, P. M. (2004). The Judge's Task to Find Law Under the Indonesian Law. YURIDIKA, 19(2). https://doi.org/http://dx.doi.org/10.20473/ydk.v19i2.14410

Raharjo, A. (2008). Problematika Asas Retroaktif Dalam Hukum Pidana Indonesia. Jurnal Dinamika Hukum, 8(1), 70-80. Retrieved from http://dinamikahukum.fh.unsoed.ac.id/index.php/JDH/article/view/36

Samekto, F. A. (2014). Mengungkap Relasi Kapitalisme, Demokrasi Dan Globalisasi (Kajian Dalam Perspektif Studi Hukum Kritis). Jurnal Dinamika Hukum, 14(2), 301-309. https://doi.org/10.20884/1.jdh.2014.14.2.298

Shah, A. (2005). Public Services Delivery (Public Sector, Governance, and Accountability) (Public Sector, Governance, and Accountability Series). World Bank Publications. https://doi.org/10.1596/978-0-8213-6140-5

Soerjono, S. (1986). Pengantar Penelitian Hukum. Universitas Indonesia Press.

Sulistyanta. (2013). Implikasi Tindak Pidana Di Luar KUHP Dalam Hukum Acara Pidana (Studi Kasus Taraf Sinkronisasi). Jurnal Dinamika Hukum, 13(2), 185-187. Retrieved from http://dinamikahukum.fh.unsoed.ac.id/index.php/JDH/article/viewFile/202/ 165

The International Organization Consumers Unions. (1991). The International Organization Consumers Unions. Environment and Urbanization, 3(1), pp: 153-159 https://doi.org/10.1177/095624789100300115

Tinungki, Jeniffer Poelmarie. (2019). Kewajiban Dokter dalam Membuat Rekam Medis Menurut Undang-Undang No. 29 Tahun 2004. Jurnal Lex Et Societatis $\operatorname{VII}(5)$. 